\title{
The first mathematics textbook printed in Moldavia. Elementi aritmetice arătate firești (Iași, 1795)
}

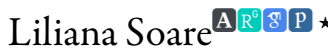 \\ Faculty of Letters, University of Pitești, Str. Gh. Doja 41, 110253 Pitești, Romania
}

\begin{abstract}
Article info
History:

Received September 15, 2021

Accepted October 7, 2021

Published December 12, 2021

Key words:

Amfilohie Hotiniul

Italian influence

mathematics

translation

Abstract

The first mathematics textbook printed in Moldavia (Iaşi, 1795) was not sufficiently examined, although the translation offers us valuable information on the Italian influence on the Romanian language and a precious linguistic material as regards both the configuration of the Romanian literary language in Moldavia at the end of the $18^{\text {th }}$ century and the constitution of mathematical terminology. The linguistic material excerpted reflects phonetic and morphologic norms specific of the author's dialect, sometimes going beyond the criteria illustrated by the local tradition, especially in the morphosyntax field. The lack of a terminological tradition is to be observed in the high number of un-adapted terms, semantic loans and old terms. Amfilohie's intense activity of translating from Italian (the scholar being a genuine forerunner of the Italianate movement in Moldavia) is proof of the depths of the cultural contacts with the western world, resulting in the intensification of the renewing of the Romanian vocabulary by assimilating Latin-Romance borrowings in general and Italian ones, in particular.
\end{abstract}

\section{Introduction}

In Moldavia, the first mathematical texts dates back in $1795^{1}$ : the elementary manuscript mathematics written by Matei Millo and the mathematics of Amfilohie Hotiniul, Elementi aritmetice arătate firești [Naturally-Demonstrated Elements of Arithmetic], printed in Iași. It was shown that the Romanian translation was made around 1784 and circulated in manuscript (Ursu, 1962, p. 98-99; Șuiu, 1979, p. 33; Dima \& Dima, 2016, p. 277), being used in the Princely Academy of Iași, in the school of the Putna monastery and in other schools of the time. After such an intense circulation as a manuscript, it was finally published on December $11^{\text {th }}, 1795$, in a volume of 168 pages.

\section{The Italian source}

The original is a mathematics textbook written by Alessandro Conti and printed in Rome in a first edition which has remained lost up to our days.

The second edition (indicated as such in the title sheet - Seconda edizione) also appears in Rome, in 1741, and it is entitled Elementi aritmetici ne' quali si contengono tutte le operazioni principali dell' aritmetica. Coll aggiunta di alcuni precetti di agrimensura [Arithmetic elements in which all the main operations of arithmetic are contained. With the addition of some precepts of surveying]. The author's first name and profession also appear on the title page: (Dati în luce dal) P. Alessandro Maria di S. Matteo, Sacerdote professo de' chierici regolari della Madre di Dio delle Scuole Pie. This second edition has 238 pages, and the table of contents only renders the titles. In the paper, however, the notions are structured

\footnotetext{
^Email address: lilianasoare2006@yahoo.com.

${ }^{1}$ By this time, three prints in the field of mathematics had appeared in Transylvania, which held cultural primacy (1777, $1785,1789)$.
} 
in 23 chapters numbered with Roman numerals: the first 18 chapters contain the main rules of calculation, but also fundamental rules, such as the simple rule of three, and the next 5 chapters (Aggiunta. Principi de agrimensura) present notions of geometry (information about geometric figures: triangle, square, rectangle, rhombus, rhomboid, trapezoid, parallelogram, pentagon, hexagon, circle and the rules for calculating their surfaces).

The third edition also appears in Rome, in 1757, in a volume of 228 pages, structured in 21 chapters, without geometry notions, but with a final chapter on company accounting issues. This edition also contains the full name of the author: Alessandro Conti. The fourth edition appears in 1774, and the fift - in 1800 .

We do not know if Amfilohie was familiar with the 1741 edition, but, if it was accessible to him, he did not fully capitalize on the chapter dedicated to geometry, because the information (and the way in which content was organized) presented by him exceeds the original. As noted, Amfilohie may very well have used several sources in writing this part, such as Rutilio Benincasa's L'economia del cittadino in villa and Almanacco perpetuo, the 1720 edition (Șuiu, 1979, p. 34; Dima \& Dima, 2016, p. 278). For example, Almanacco perpetuo, with a wide circulation and numerous editions, deals, among many and varied topics of interest, with topography and geometry issues, which are also found in Amfilohie's translation, such as defining geometry, its types, presentation of distance measurement units (leghe, miglia, stadi, passi, piedi, palmi) of algebraic concepts (such as square root, number and cubic root) or of geometric concepts (point and line, fundamental concepts of Euclidean geometry). The terminology used by Amfilohie is tributary to the Italian source: terminological phrases aritmetica gheometricească, aritmetica gheometrii[ $i]$ - It. aritmetica geometrica, număr cub - It. numero cubo, rădăcină cfădrată - It. radice quadrata, rădăcină cubă - It. radice cuba, etc., the terms that describe angular measures: grad - It. grado, minute - It. minuto, $-i$, second / seconde - It. secondo, $-i$, terț $i$ - It. terzo, $-i$ or the structure containing a term that has not been imposed, de cozmometri, adecă de măsurătorii lumii, which is transposed as such from the source text: cosmimetri e misuratori del mondo.

However, given the impressive number of didactic texts and of science popularization texts that circulated in eighteenth-century Italy, we believe that it is possible to capitalize on another work "containing elements of the two mentioned above and corresponding more precisely to the part of geometry from Amfilohie's volume" (Dima \& Dima, 2016, p. 278).

\section{The structure and particularities of translation and organization of the Romanian text}

3.1. Sheets I-V, which contain the preface (Cătră cei din darul Sfîntului Duh fii sufletești, a sfintei biserici cetitori), were numbered mechanically by the library. The work has a numbering defect starting with page 165, wrongly numbered 155 (the next one is 154, then 519). A typographical error also appears in the summary of the paper, where (page) 14 is written instead of (page) 41 . On page 72 , the following sequence is found: "După cum s-au arătat la fila ()", but the number of the page to which the reference is made is not written in between parentheses. There are some inconsistencies regarding the titles of the chapters as they appear in the table of contents and in the body of the paper; for example, in Scara de toate ce să află în această cărticică, Chapter 10 is entitled Pentru întoarcere rămășițelor, whilst in the paper - Pentru orînduiala întoarcerii, Chapter 11 - Pentru prețuire rămășițelor, whilst in the text - Pentru orînduiala prețirii.

3.2. In the preface, the importance of the work is stated as consisting in the latter's eminently utilitarian purpose: "Și pentru aceasta, văzînd noi bunătatea și mărirea aceștii cărți, am silit din toată prostia științii mele de am tîlcuit-o și am așezat-o după al nostru obiceiu de numărare și în limba noastră moldovenească, fiind atîta de trebuincioasă în toate trebile vieții noastre, căci nimica nu să poate face unde să nu între acest meșteșug [...] că, fără de aceasta, noi am petrece o viață întunecată și încurcată, neștiind nici cum, și nici cîte să fie lucrurile" (III-IV). The religious perspective is natural, given his quality as a clergyman: “[...] 
însuși Dumnezeu fiind unul, iată numărul unul și cu a sa bună-voire, născînd pre al său fiu, să numi fața a doaî, iată că să făcu și al doilea număr și, suflînd Dumnezeu dintru a sa ființă și înțelegere, suflarea cea sfîntă a sa, să făcu și al treilea număr [...] Și, după aceasta, să mai zice și în sfintele biblii cum că Dumnezeu au făcut lumea în 6 zile, care număr de 6 este cel mai iscusit între aritmetice, ajungîndu-să încă și al 7 număr, că de siriiani să cheamă sabba și de alții sabbato, iară de noi, sîmbătă, că să închipuiește o zi de odihnă” (II-III).

3.3. The Moldavian scholar adapts the content to local realities; thus, on pages 3 and 4 , he shows the correspondence between Cyrillic letters and Arabic numerals; in the chapter Pentru măsurile care să obicinuiesc in gheometria practica, in addition to the international units of measurement: stadie, milă, legă, picioru Parijului, piciorul Romii, piciorul vespian ${ }^{2}$ (133), Amfilohie also indicates the units of measurement used "la noi, în Moldova" (132): palma domnească, piciorul, prăjina. One can observe that the units of measurement vary in time and space: "Gheometrii cei vechi făcé pasu de 5 picioare, iar acum să obicinuiește de 6 - după cum și aici, la noi, în Moldova, că să face de 6 palme domnești. Cu 3 de acești pași fac o prăjină de a Parijului, însă cu a lor măsură de picior [...] În multe și în multe chipuri măsoară oamenii în lume, iară noi să căutăm a noastre obiceiuri de aicea și să vedem de să potrivesc cu a altora" (132-133) and that for some of them it is difficult to find an equivalence: "Și mai întîi vom zice despre picioru Parijului, că nu să potrivește nici cu palma domnească de aicea, nici cu piciorul cel vechiu al Romii [...]" (133).

However, units of measurement are found throughout the text, being occasioned by the presentation of some practical applications of arithmetic: monetary units: lei $(12,13,110$, etc.), părale $(12,13,110$, etc.), bani (13, 110, etc.), orți (109, adecă în a patra parte dintr-un leu), zlot "monedă de argint care, la începutul secolului al XIX-lea, valora 30 de parale" (107); units of measurement for capacity and weight: cintare $(63,72$, cantare, 72 , cantariu, 72$)$, dramuri $(63,110)$, litre $(63,110)$, ocă $(72,162$, oci, 63 , $110)$, vedre $(162,163,164)$; units of measurement for lengths and areas: $\cot (72, \operatorname{coti} i, 75,110)$, deget (132, 135), grefuri $(75$, grefi, 75, 110), palma (163, palme, 163), palmă domnească (132, palma domnească a Moldovii, 135, palme domnești, 163), pasu gheometric (132, pasu gheometricesc, 163: de 6 picioare au palme domnești), picior (132, picioare, 163), rupi $(75,110)$.

3.4. The text is structured in 18 chapters, less than in the Italian source text, which shows that Amfilohie processed and synthesized the content ${ }^{3}$ : Chapter 1: Pentru aritmetica. Pentru figuri. Chapter 2: Pentru izvodire figurilor. Chapter 3: Pentru număr. Chapter 4: Pentru somare. Chapter 5: Pentru tragere. Chapter 6: Pentru inmulțire. Pentru tabla pitagorica. Pentru înmulțire în cruce. Pentru inmulțire în 2 figu[ri]. Pentru înmulțire cu multe figuri. Pentru incredințare de 7:9. Chapter 7: Pentru împărțire. Chapter 8: Pentru numere rămăşițe. Chapter 9: Pentru schimbare rămăşițelor. Chapter 10: Pentru întoarcere rămăşițelor. Chapter 11: Pentru prețuire rămăşițelor. Chapter 12: Pentru somare rămășițtelor. Chapter 13: Pentru tragere rămășițelor. Chapter 14: Pentru înmulțire rămășițelor. Pentru înmulțire numărul întreg și cu rămășițe pe numărul întreg. Pentru înmulțire numărul întreg, pe numărul întreg și cu rămășițe. Pentru inmulțire numărul întreg și cu rămășiță. Chapter 15: Pentru orînduiala de trei. Chapter 16: Pentru orînduiala de 5, 7, 9și 11. Chapter 17: Pentru orînduiala tovărăşiei neguţtorești. Chapter 18: Pentru aritmetica gheometrii[i]. Pentru măsuri. Pentru numere cfadre și rădăcina cfădrată. Pentru cfadrare numerilor. Pentru găsire rădăcinii. Pentru învățetura măsurii de vase.

If in the table of contents the chapters are numbered with Roman numerals, in the body of the paper

\footnotetext{
${ }^{2} \mathrm{O}$ stadie, au cum zic rusii, verstă, cuprinde o sută doaîzeci și cinci de pași. O milă italienească cuprinde 1000 de pași ori 8 stadii. O legă cuprinde 4000 de pași ori 32 de stadii. O milă nemțască cuprinde 5000 de pași au 40 de stadii [...]

${ }^{3}$ For instance, two chapters (Della regola del tre and Della regola del tre rovescia) are united in one by Amfilohie (Pentru orinduiala de trei), and four chapters (Della regola del cinque dritta, Della regola del cinque rovescia, Della regola del sette e del nove, Della regola del tre moltiplice) are synthesized into one (Pentru orinduiala de 5, 7, 9 și 11). The last chapter of the Italian text, on the accounting of commercial companies (Delle compagnie mercantili), is preserved and capitalized as such: Pentru orînduiala tovărășiei neguțtorești. Tovărășia neguțtorească 'company; commercial association' este definită ca o tocmală intre doầ au mai multe fețe neguțtorești, puind bani au marfă în tovărășie au slujbă și istețime, dar să tîmplă că la o vreme vine ca să aibă socotelile lor de cîștig ori de pagubă (119-120).
} 
they are numbered with Cyrillic.

3.5. Due to its didactic purpose, the volume is conceived under the form of questions and answers, the Moldavian scholar keeping the organization type of the original. Dialogue is the most efficient way to structure the popularizing text; the scientific component of the text is associated with dialogic forms, in statements strongly oriented to the recipient:

"î. Ce este gheometrie?

R. Gheometrie este cuvînt grecesc, că în limba noastră nu zice altă fără decît măsurarea pămîntului și este de doao feliuri, una să cheamă latinește speculativa și alta practica, că iarăși în limba noastră și aceste cuvinte să tîlcuiesc cu luarea aminte de amăruntul, că, după cuvîntul lor, să poate zice și oglinditoare și alta cu lucrare, că cu bună nădăjduire și cu îndrăznire măsoară fieștecare trup pentru care măsuri voim ca să arătăm cîte oarece cum fac ei măsurile și cu ce chip de numărare numără” ${ }^{4}(131)$.

Definitions, explanations, classifications are mechanisms specific to didactic and popularised science texts: “Un angol să cheamă unde să împreună doaî linii la vîrf” (140); “Un triangolu să cheamă cînd trei linéi să împreună în vîrfuri în trei locuri prinpregiur și să cheamă în multe chipuri, angolu drept, angolu ascuțit, angolu tîmpit și isocile, că toate au măsurile sale osebite. După aceste, vin scfadrile, adecă cfădrate de multe feliuri, cumu-i cfădratu întocma, cfădratu lung, rombu, romboide" (141).

3.6. Without attempting an analysis of the translation strategies, we can notice that, being a scientific paper in such a precise and rigorous field, the Moldavian scholar tries to stay as close as possible to the original, but due to the terminological difficulty and richness of the material, he prefers to simplify the text, by synthesizing reformulations or by eliminations:

Î. Cîte sînt părțile aritmeticii? $\quad$ D. Quante sono le parti dell' aritmetica?

R. Cinci: numărare, somare, tragere, înmulțire şi împărţire, care toate aceste părți au rînduielele lor osebite și cu încredințări fără de grașală, că fieștecine sîngur de sîne poate cunoaște lucrînd de au greșit au nu (6).
R. Quantunque apresso alcuni il numerare non sia stimata una delle operazioni dell' aritmetica, contuttociò, perchè questa deve procedere alle altre operazioni, dico, che sono cinque, cioè numerare, sommare, sottrarre, moltiplicare e partire.

D. Tutte le sudette operazioni hanno le fue prove particolari ed infallibili?

R. Certo che sì, di modo tale, che ogn' uno può da sè stesso conoscere se avrá fallito, o nò.

\section{Î. Ce va să zică somare?}

D. Che cosa vuol dir sommare?

R. Nu va să zică altă fără decît unire ori strîngere într-un loc multe părți de numere întru o singură parte.

Î. Cîte părți de numere trebuie ca să se facă somare?

R. Pot să fie cît de multe, dar, mai puține de 2, nu să pot soma. (10)

R. Unire più partite de numeri che sian della medesima specie in una sola partita.

D. Questa unione de partite come si chiama aritmeticamente?

R. La somma.

D. Quante di queste partite ci vogliono per il sommare?

R. Possono essere infinite, ma però non puo darsi sommazione alcuna minore di due partite.

${ }^{4}$ The example is also relevant to the etymological explanations provided and the attempts to find the best equivalent of the new terms. 
When comparing the texts, one also observes that whole passages are eliminated: mathematical demonstrations, quotations or references to other texts (especially Euclid's), probably considered too difficult or useless for the target audience.

Very often, Amfilohie introduces explanatory interpolations and additional information. These elaborations are felt as necessary, given the didactic character of the translation (for example, in the chapter on subtraction, Amfilohie gives several examples, in the chapter on multiplication he introduces the multiplication table, parts that are missing from the original, etc.); the text therefore contains many original passages.

\begin{tabular}{ll}
\hline Î: Ce lucru este aritmetica? & Domanda: Che cosa é aritmetica? \\
R: Aritmetica este un meșteșug de a pune & Risposta: E' un arte di calculare i numeri ed é \\
numerile în orînduială, pentru ca să se poată & una parte della matematica, la quale senza \\
cunoaște socoteala lor și este o parte de a & questa non può apprendersi. \\
matimaticii. & D. Di quante forte é l' aritmetica? \\
Î: Pe ce limbă să numește aritmetica? & R. Di due forte, cioè aritmetica speculativa ed \\
R: Grecește (aritmetichi), că în limba noastră & aritmetica prattica. \\
nu zice altă fără decît meșteșugul numărării au & D. Che cosa é aritmetica speculativa? \\
invățătura numărului. & R. E' una certa speculazione dell nostro \\
Î. De cîte feliuri este aritmetichi ori această & intelletto, con cui si considerano le qualità, \\
innvățătură? & proprietà e proporzioni de numeri, \\
R: De doaî feliuri, una care să face cu socotința & separatamente da ogni materia. \\
gîndirii și alta cu lucrare. & D. Che cosa é aritmetica prattica? \\
Î: Ce lucru va să zică cu socotința gîndirii? & R. E’ la medesima aritmetica speculativa posta \\
R: Aceea care îi zic latinii speculativă, că limba & in prattica, la quale consiste nell' atto \\
noastră ar zice luare de samă (1) cu amăruntul, & medesimo di calcolare. \\
la apropierile, feliurile și tocmirile numerilor. & \\
Î: Dară cea cu lucrare care este? & \\
R: Aceea care să așază numirile cu aceiași & \\
orînduială ca și speculativa, numai cu & \\
orînduiala care să face den afară pentru a & \\
noastre de obște trebi, pentru care noi acum & \\
voim ca să vorbim (2). & \\
\hline
\end{tabular}

3.7. The elementary mathematical operations are called: somare 'addition' (It. sommare), tragere 'subtraction', înmulțire 'multiplication' and impărțire 'division' (6).

The calque rămăşiță is used with two meanings taken from the Italian original: 'difference, the result of a subtraction' (14, etc.; It. differenza) and 'remainder', by which one is to understand 'the value left over after performing a division' (41,42; It. rotto): Rămășițele sînt oarecare numere rămase, că să întîmplă de la impărțirile numerilor au dintr-alte lucruri numărîndu-se [...] $\frac{2}{3} \frac{3}{4} \frac{7}{8}$ (41-42), rămășița $\frac{7}{12}$ (55), etc.

The verb agiunge 'to add' (< It. aggiungere), a semantic calque, occurs extremely frequently: îlfă zăcină și-l ajunge cu 5, că face 15 (36), inmulțește 34 cu 26 și agiunge 1 la somă (41), să preface numărul acesta în numire numinătoriului de la a sa rămășiță și la somă să agiungi și numărătoriul (101), înmulțeşte și pe numărul cel dintîi, dar la acesta să nu să agiungă numărătoriul (103), etc.

There are also many structures with veni 'to result in, to yield, to give', as calques after Italian (viene: talqué dividendosi [...] ne viene 2; il quale finalmente diviso per 4500 ne viene 60 etc. și viene + infinitiv: viene a dividere, viene ad essere etc.): înmulțindu-să cu 3 și agiungîndu-să 1 la somă, vine tocma numărul impărțit (40), dar tot să pot întoarce de a veni la o sîngură măsură amîndoầ (93), [...] și înmulțindu-să 21 cu 5 vine iară 105 (99), puindu-să acest 24 pe supt toți numărătorii, vin a fi întoarse într-o singură numire (69), că vin a fi 210 (54), că vin a fi un ban (61), orînduiala vine a să pune într-acest feliu așa (102) etc. 
Digits are called figuri (of arithmetic) (after the Italian phrase le figure aritmetiche). Zero, 'figure without a name', is called cifra $(4,148,149, \underline{t} \text { ifra, 2, 152) or nimică (It. nulla) })^{5}$ : "iară pe cea fără de nume o numim țifra ori nimică, că să face ca un 0 au cercușor, că slujaște pentru ca să încheie zecína” (2); “[...] luînd sama că cifra, puindu-să, adaoge zecíni, ori de sute, ori de mii ori de care alt număr" (4).

Numbers ("Numărul este o adunătură de unime ori de lucruri adunate", 5) are of three types: număr curat (It. numero semplice), from 1 to 9 (therefore, the simple cardinals), număr inchiet (It. numero articolo), that is, cardinals composed of a simple numeral from 1 to 9 + the noun zeci $(10-20-30-$ $40-[\ldots]-90$, p. 6; in the original, it is shown that numero articolo is any number that ends in 0:10,30, 500, 240), and număr insoțit (It. numero misto), that is, mixed-structure cardinals, in the composition of which there are all types of numerals. Dozens are named zecini (It. decine).

\section{Linguistic peculiarities}

\subsection{Phonetics}

- the affricate $\breve{g}$ alternates with the voiced fricative $j$, the ratio being balanced: agiunge $(16,31,53$,

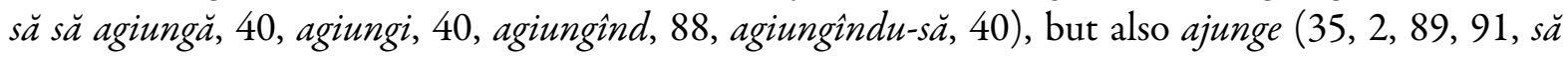
li să ajungă, 106, ajungîndu-le, 108); gios (2, 15, 85), but also jos (140, 148); giumătate (43, 158, giumătatea, 14, giumătăți, 109), but also jumătate (107, 164); împregiurare (160), but also imprejurare (140); primpregiur $(141,160)$, but also primprejur (160). We have only recorded a single situation in which there are no fluctuations in the use of the affricate: agiutoriu (162) or of the fricative: mijloc $(42,116)$.

- phonetisms with a velar $j, s, s,,, z:$ aşază $(2,96)$, greşală $(6,58,95)$, să împărtășaște (96), să se împărțască (35, 38), să se înmulțască (24, vrei să înmulțăști, 26, inmulțăște, 80), te înştiințăz $(9,58)$, neguțtorie (128), neguțtoriu (125), sama (136), săvîrșaște (8), sîne (6, 159), sîngur (6, sîngură, 68), slujaște (2, 28, 36, 108, 155), zăcina (11). Often, they alternate with weak forms: să impărțește (36, să o impărțesti, 97), să înmulțește (35), îțelege (I), invățetura (VII), învățind (161), lăsind (134), neguțitoriu (75, 129), sine (159), se slujesc (132, 145), t,erile (IV), zecina (2), etc.

- velar labial m: tocmală (IV, 119).

- intact labial $f$ : fier (136).

- The palatal timbre of the vibrant $r$ is rendered consistently in words derived with -tor: folositoriu (5), impărțitoriul (32), înmulțitoriu (24), neguțătoriu (128), petrecătoriu ori cuprinzătoriu (35), purtătoriu (168), tocmitoriu ( aritmeticii, 5), etc., but also in non-derived words: cantariu (72).

- velar $r$ : unsprăzece (6), doaăsprăzece (6).

- closure of medial atone $e$ into $i$ : intriite (166), numerile (1), rămăşițile (41).

- protonic $\breve{a}>a$ in one single situation: macar (165), a single-occurrence lexeme; otherwise, only the măcar phonetism is employed.

- atone $a>$ ă: păra (60, părale, 12).

- $o>u$ in cuprinde $(155,163)$.

- ă preserved in mulțămită (5).

- î preserved in întra: întră (39, întrînd, 39, întrate, 38).

- $n>r$, by dissimilation: cu amăruntul $(2,131)$.

- final ea > é: i s-ar cădé (125), cé (134), le făcé (132), va încăpé (64), n-am puté (II), li-i vedé (141), vei vré (32), etc.

- medial $e$ not passed into $i$ in să cetesc (32), cetitori (I), den (2).

- $l$ ' in feliu and its derivatives. Amfilohie uses exclusively the palatalized form of this noun (< Hung. féle).

\footnotetext{
${ }^{5}$ Ilie I. Popa correctly pointed out that the term figură 'digit' was taken by Amfilohie from the Italian text, where, in turn, it came from medieval Latin, whilst the term figure cifră 'zero' was taken from Neo-Greek (Popa, 1938, p. 69-73).
} 


\subsection{Morphosyntax}

- old plural forms: mormînturi (134), obiceie (146), socotelele (120), trebile (III), vremile (128). The noun timp is classified as masculine, with the plural form of timpii (128: Dară de vorfi banii de fieștecare neguțătoriu într-un chip puşi, iară timpii vor avé osebire, cum s-ar socoti aceştie?)

- The atomistic declension, inherited from Latin, which involves an ending-based marking for both elements of the phrase, is to be found only on the title page: in zilele preluminatului și preinălțatului domnului nostru Alexandru Ioan Calimab Voievod.

- Regarding the synthetic marking of the feminine singular, one can observe the presence of the forms presenting the inflectional -ii: gheometriii (137), linii[i] (151), Moldovii (135), Romii (133), științii (III) which alternate with those in -ei: liniei (49), tipografiei (168), tovărășiei (119).

- The genitive is marked both synthetically: incredințarea somării (15), incredințarea tragerii (22), rădăcina cfadratului (146), diametru cercului (163), inmulțirea rămășițelor (81), etc., as well as analytically, with the proclitic morpheme lui: cornul lui her $(33)^{6}$, pomenirile lui Vespasian impărat (134), or mixed, with a possessive mark: numărul este o lucrare a aritmeticii (9), cu această orînduială a prețiirii (62), acest meșteșug al gheometrii[i] (137), delta tiparnică a grecilor (154), etc.

- The marking with the preposition $a$, when the first element of the nominal group is invariable in terms of case, is not performed: unire ori strîngere intr-un loc multe părți de numere întru o singură parte (10).

- The preposition $l a$ is rarely used to express analytical genitive, in structures that contain inflectional or indefinite quantifiers: orînduială și tocmală la toată fapta omenească și la fieștecare alt lucru (IV), but also without: rămăşița la numărul ce s-au inmulțit (91).

- Most often, the analytical marking of the genitive is performed by the functional preposition $d e^{7}$. The text abounds in prepositional genitive structures, of the type (un)determined noun $+d e+$ nominal / nominal group, a phenomenon that represents a characteristic of Amfilohie's writing, also present in the other translations: grădina de Edem (sic! II), numărul de stele și planete (II), acest meşteșug și învățătură de aritmetică (III), incepători de această învățătură (7), somele de aceste (53), chipurile de astronomie și de alte meșteșuguri (III), inchipuire de toate figurile aceste (2), săvîrșirea periodului de milioane (8), numărul de zecine (31), prețuirea de fieștecare rămășiță (71), tragere de rămășiță (79), Cum să fac încredințările de trei închipuiri de inmulțire de rămășițe ce s-au dat mai sus? (90), încredințările de aceste orinduiele (110), zidurile de la a sa curte (134), măsura piciorului de Pariji (136), inceputul și sfirșitul de toate aceste nume (137), cu aceste împărțiri de linii (140), află atocmare și măsura de fieștecare figură gheometricească (140), rădăcina de numere (141), m-am îndatorit cu arătare de aceste figuri (155), tainele de această învățătură (155), rădăcina de acest număr (158), fața de un cerc (160), in predoslovie de această cărticică (165), purtătoriu de grijă tipografiei (168), etc. This feature of the old language is reinforced by the transposition of some constructions from the Italian original with $d i, d e$, and del: somma di questi due prodotti, unione di partite, radice quadrata di questo numero; del sommare de' rotti, del sottrarre de' rotti, valutare de' rotti, periodo de' millioni; scienza del aritmetica, prova del valutare, superficie del circolo etc.

- The variation of structures with synthetic genitive and prepositionally-constructed genitive is often observed on the same page: pentru tragere rămăşițelor - Cum să face tragere de rămășițe? (79), membro de dilioane (9) - membro dilioanelor (10), soma de pași (157, 159) - soma pașilor (157, 159), inmulțire de rămășițe (90) - pentru înmulțire rămăşșțelor (VII), etc.

- Analytical structures equivalent to the genitive also appear by calquing the Italian constructions with della (of the type prodotto della moltiplicazione), in nominal group without or with various determiners and quantifiers: soma de la părale (12), figurile de la soma înmulțită (34), că avu ieșire somii de la înmulțire (92); numărul de la întîia înmulțire (29), țfrele de la amîndoî numerile (31), numinătoriul de la al doile rămăşiță (57), numinătoriul de la acestaşi rămăşiță înmulțitoare (87), etc.

\footnotetext{
${ }^{6}$ Cyrillic glyph.

${ }^{7}$ For this still controversial matter in Romanian grammar, see Hoinărescu (2016, p. 227-256).
} 
- Partitive phrases preferentially select the preposition de, a phenomenon explainable by the influence of the Italian language: parte de un membro (10), multe părți de numere (10), jumătate de ceară (107), giumătate de impregiurarea cercului $(160,161)$, giumătate de diametru $(160,161)$, părticică de materie (137), sometimes with an embedded genitive group: oparte de a matimaticii (1), părți de a numărului intreg (64), altepărţide-a faptei (116), un grad de-a meridianului au cercului de amiazăzi (133), acestea sînt un lucru de a gheometrii [i], nu-i aşa? (137), fieștecare parte de a cercului (139). Less seldom, the dintr (-): a patra parte dintr-o ocă (105), a patra parte dintr-un leu (109) and din: aceasta este una din cele adînci învățături (155) prepositions also appear.

- The frequency of nominal groups with a nominal center in the genitive in which the determiner (most often a noun of verbal origin) is indefinite is a feature of Amfilohie's writing and falls within the Moldavian literary norm of the period: pentru prețuire rămășițelor (VI), pentru inmulțire rămășițelor (VII), pentru găsire rădăcinii (VII), încredințare înmulțirii (32), Incredințarea de aceste să face cu prețuire somii rămășiţelor (69), să poate face și întru alt feliu, cu intoarcere numerilor (100), cu somare capetelor de bani (120), să vedem și parte neguțitoriului B (124), etc. They alternate with the defined shapes of the determiner: pentru izvodire figurilor (VII) - pentru izvodirea figurilor (4), pentru somare rămășiţelor (VI) - somarea rămășițelor (22) - in somarea feților (157), pentru schimbare rămășițelor (VII) - pentru schimbarea rămășițelor (45), avu ieșire somii de la înmulțire (92) - ieșirea somii (92).

- Rather uncommonly, there are structures within which the random unmarked noun appears in the syntactic position of the genitive (unmarked genitive): pentru înmulțire numărul întreg (VII), Incredințarea să face cu înmulțire împărțitoriul cu numărul petrecătoriu (40), cu tragere rădăcina cfadratului (150), iată închipuire aceste numere (156).

- the invariability of the possessive mark: a sfintei biserici cetitori (I), a lor depărtări și întoarceri (II), multe sînt gîndurile unora și a altora (5), alte două părți a faptei (116), noi să căutăm a noastre obiceiuri de aicea și să vedem de să potrivesc cu a altora (133), întru a sale lucrări (146), a gheometrilor obiceie (146), etc.

- As a rule, the agreement with the oblique cases in the nominal group is not made: pune-l in capul linii $[i]$ trasă $(151,153)$, but one can notice, sometimes even on the same page, the alternation of constructions with or without agreement: numinătoriul rămășiţii găsite (55), numinătoriul rămășiții găsită (55).

- The determiner $c e l$ appears in most cases placed after the noun, in polydefinite structures: leul cel imprumutat (21), numărul cel mic (22), numărul cel mare (22), degetul cel mare (26), numărul cel dintîi (103), piciorul cel vechiu (133), etc. but, less frequently, also before the noun: cel abaco care să găsește (24), sometimes with other constituents interspersed: cea despre mîna dreaptă figură (7).

- The genitive-dative of the determiner $c e l$ is, in the feminine singular, cei, an etymological form (<ecce + illai), and not celei, analogical form, after the plural: rămăşsții cei dintîi (55), rămăşsții cei mai mari (80), în dreptul cei deasupra some (85), pricini răspunzătoare lucrării cei pusă în mijloc (116), etc.

- The genitive-dative of the feminine demonstrative of nearness has the etymological form aceștii: bunătatea și mărirea aceștii cărți (III), ieșirea aceștii împărțiri (59) and aceștia, in postposition: numinătoriul rămășiţii aceștia (103), pentru incredințtarea aceștia (108), and, for the masculine, we recorded the genitive form acestuie ( $i a>i e)$ : să se inmulțască soma acestuie (93). The demonstrative of nearness for the right cases is aceste, for the feminine: fă somă de aceste părale (72) and acești: acești 10 orţi (10), sometimes aceştie: $(128$, dintru aceștie lei, 14) for the masculine. The scholar also uses forms with apheresis: ceastă inchipuire (7), ceastă cruce (50). The demonstrative pronominal adjective placed before the noun has the deictic particle $-a$ : intr-acesta feliu (31), as well as the indefinite article: banii unuia neguţtoriu $(125)^{8}$.

- Other aspects of the use of demonstrative and identity determiners concern the old forms of the

\footnotetext{
${ }^{8}$ We may also encounter an accidental confusion between the indefinite article and the indefinite pronoun unul (banii
} unuia care era neguțtoriu). 
demonstrative of differentiation: ceealaltă (14), cielalți doi (17), celalalt $(16,29)$, celuielalt (34), cestuialalt (96), and of identity, also sometimes used with the old form aceastaşi, acestaşi: numinătoriul de la aceastaşi rămășiță (87), rămășsița de acestași (91), să face înmulțire de acestași (118), but, more frequently, with the current form: același / aceluiași: același număr (30), același preț (46, numărul schimbătoriu este același, 46), același chip și obiceiu (132), aceluiaşi înmulțitoriu (29).

- indefinite compounds with fiește-: fieştecine (6), fieştecare (30,71), ori-loare-: oricine (134), oarecare $(46,68)$, oarece $(131)$ and -va: cineva (115). A special mention is the form vreoarecare: cind să vor intîmpla vreoarecare din figurile cele din numărul... (19), a schimba vreoarecare rămășițe întru numire mai mică $(45$, cf. also 46, 99).

- indefinite quantitative niscai (< Lat. nescio qualem): niscai some (14), niscai măsuri (136).

- variable forms of the relative pronoun: carele (30), carii (IV), etc.

- $c a ̆$ is used with a relative pronoun value: ce, care (It. che; in Italian, che is also a subordinate conjunction, which corresponds to că from Romanian): aceea care $\hat{\imath} i$ zic latinii speculativă, că in limba noastră ar zice luare de samă cu amăruntul (1), noi vom săvîrși aceste orînduiele de rămășițe și vom merge la altă parte, că să cheamă orînduiala de trei (95), veți ști că în orînduiala de trei mai este și alta, că să cheamă intoars $\breve{a}(111)$, orînduiala de trei mai are o dogmă, că să cheamă orînduiala înmulțitoare (119), linia cercului, că să cheamă linia de primprejur (139), etc.

- The use of unaccorded forms of emphatic pronominal adjectives falls within the norm of the time: insuşi mina lui Dumnezeu (III).

- The forms in -le of the ordinal numeral are much more common than the forms in -lea (we cannot have full certainty that the extension is explicable by the monophthongization of $e a>e$, a phenomenon that is also observed in the case of verbs, or that we are dealing exclusively with old forms, without the particle $a$ ), and appear unaccorded in gender with the regent (with few exceptions, exclusively masculine forms): al doile inchipuire (41), al doile rămășiţă (65), de la al doile rămăşiţă (55), cea de al doile înmulțire (92), al doile tablă (103), somă de al doile (77), alpatrule orînduială (159), al șaptezecile și a cincea parte (47), rămășiții de al treile (55), numărul de al patrule (111), but also: a treia parte, a patra parte, a cincea parte (43); al doilea numărătoriu (67), al doilea rămăşiţă (68), al treilea orînduială (159), etc.

- they also appear as discursive connectors, used for textual organization: Intrucît incepură de nevoie a căuta măsurile vechi, din pomenirile lui Vespasian impărat și de la alte semne care s-au aflat, întîi: picioare săpate în piatrăpe la mormînturi; al doile: săpate în fier și spije; al treile: în măsurile de locuri și mile; al patrule: în măsurile piciorului ce au lăsat vrednicul Congiu Farnezianu pe zidurile de la a sa curte in Roma (134).

- the collective numeral: amîndoaî (31,32), tustrele locurile (106), the fractional numeral (which retains the Latin configuration: tertia, quarta ... pars): a treia parte (43), a patra parte $(43,105)$, a cincea parte $(43,52)$, a opta parte (52), giumătate de diametru $(160,161), 14$ și jumătate (164), opt jumătăți (164), 13 ceasuri și un cifert (103), the multiplicative numeral: de figuri întriite (166), indoită (156) and the iterative numeral, in simple constructions: incape de cinci ori (85) or more complex ones: de trei ori a opta parte (52), de şapte ori a opta parte (52), de două ori a treia parte (82), etc.

- the use of iotacized verbal forms, most often in alternation with the restored dental forms: poci (161), puind (8, 30, puindu-să, 4, 71); va rămîne $(10,14)$, but să rămîie $(21,100$, rămîind, 48, rămîindu-ne, 72); să vază (102), but să văd (7).

- The compound perfect indicative presents, in the singular, homonymous forms with the plural, etymological forms used exclusively in all literary variants of Old Romanian: numărul ce s-au inmulțit (37), rămășiţa ce-au fost împărțitoare (48), soma care au ieșit de la înmulțire (91), este o minune cum sau păzit întru această țară o măsură atìta de veche (136), numărul ce s-au cfădrat (150), eu mă minunez cum au găsit omul atîtea meşteșuguri (164), etc.

- The extremely high frequency of the perfect simple, while placing the action in a moment close to the moment of enunciation, is justified by the didactic character of the text, which abounds in describ- 
ing practical and problematic situations, in demonstrations, explanations and examples: cum făcuşi deasupra (19), să punem că, împărţindu-să nişte bani, rămasără dintr-un leu [...] (43), Vezi că toate rămășițele de multe numiri să întoarsără într-o sîngură rămășiță (68), că avu ieșire somii de la înmulțire (92), după cum făcuşi deasupra (105), să făcură 32 (105), pusără [...] și cîștigară (122), aceste figuri ce mi le arătaşi (145), etc. Sometimes the simple perfect is used as a time of impersonal narration, not anchored in the moment of communication: [...] insuşi Dumnezeu, find unul, iată numărul unul și cu a sa bună-voire, născînd pre al său fiu, să numi fața a doầ, iată că să făcu și al doilea număr [...] (I), cine izvodifigurile acestea (4), zisă unuia din ucenici (75), multă gîlcevire făcură gheometrii și astronomii (134), arapii izvodiră aceste figuri (167).

- The future formed by means of the auxiliary a avea and the infinitive with $a$ is rooted in a modal construction that expresses necessity, obligation (the modal value seems more important than the temporal one): avem a da mulțămită (5), avem a înmulți numărul 6 (25), avem a măsura un vas de vin (164), etc. There is also a pattern formed by the auxiliary a avea and the subjunctive, which replaces the infinitive form: avem ca să facem somă de un izvod de 5 capete (13), avem ca să scoatem ori să tragem 345 de lei şi 25 de părale din 457 de lei și 35 de părale (19), avem ca să scoatem 34 de lei (21), etc. The form of the type am să cînt is also used: ai să te imprumutezi (20), să punem că ai să împărțesti 885 de lei la 34 de oameni (37), etc., as are the popular forms specific to the Northern dialects: de nu vei vré să faci aceasta, î face cu încredințare de 9 (32), după cum îi vedés și în orînduiala prețuirii (59), și-i vedé după ce vei împărți că... (90), trage acest număr [...] că-i vedé că nu rămîne nimică (154), vor fi somele intr-un chip, a fi bine (50), și rămășița de va fi, a fi de lei (62).

- the appearance of the morpheme $a$ in the structure $a$ putea + infinitive, a structure that has a high degree of cohesion of the elements in the current phase of language: în ce chips-ar puté a inmulți și a impărți? (101), cu ce orînduială pot a-și face socotelele lor? (120).

- The impersonal a trebui appears "personalized" by agreement, with "weak" present forms: Cîte numere trebuiesc ca să se inmulțască (24), cît mai trebuiește, că trebuiesc 2 (27), Pentru ca să i să facă lungime, trebuiesc o mulțime de punte [...] (137) and as regent of a prepositionally-introduced infinitive: Cîtă somă de piatră, var, cărămidă, lemne îți trebuie de a face o zidire (162).

- The verb $a d a$ is characterized exclusively by a strong paradigm, general in the norm of the time: dede un leu și rămasără de 6 (64), dede soma de 100 (122), dede petrecere de 30 (103), dederă soma de 600000 (123), dederă ieșire de 8 (82), această orînduială o didei (118).

- The verb a fi also records an occurrence with the hypercorrect form: vezi inchipuire, că sint tocma (100).

- One can also observe the use of the short form of the third person singular of the verb a $f i$ with the prosthetic $\hat{\imath}-$, namely $\hat{\imath} i$ : acesta $\hat{\imath} i$ înmulțit cu 6 (26), deci acest $4 \hat{\imath} i$ numărul schimbătoriu (49).

- Some verbs have inflectional "suffix" forms: să se întîmpleze (II), să te împrumutezi de alta (18, 20), să strîmbează (139), with an occasional alternation of the two forms: să se împărțască $(35,38)$ - imparță (36, să se împarțe, 37), le obicinuie mai mult decît alții (5) - mai mult le obicinuiesc (138).

- Some verbs had not yet selected a certain preposition: încurcîndu-se întru măsurile meridianului (134), îți va sluji întru toate feliurile (87), chipul scrisorii lor despre dreapta spre stînga (5), să începi despre mîna dreaptă de la figura 6 a socoti (8), inmulțind un numär pre altul (24), număr înmulțit pe 5 (31), vrînd să se imparță numărul 457 pe 3 (36).

- The phenomenon of postverbal placement of pronominal or auxiliary clitics is rare, appearing in rhetorical or dubitative statements: au poate-să fără de acestea? (III), au pute-vom fără a pune inainte toate în orînduială (IV), acum să vedem pute-vom împărți și pe 42 cu 2 (99).

- The verb a se intîmpla has prefixed forms, alternating with non-prefixed ones: să va întîmpla (31), să va tîmpla (21, să tîmplă, 46).

- adverbial phrases: de istov 'completely, entirely' (21: atuncea scoate un leu din numărul deasupra imprumut, dar nu de istov, să rămîie lipsă), de iznoavă 'again' (154: pogoară de iznoavă și 04 și-i pune lîngă 22, că să vor face 2204). 
- Prepositions have old forms: cătră (I, etc.), pănă (4, 24, etc.), pre (I, II, 24, 157, etc.), preste (156, etc.), $\operatorname{supt}(11,12,69$, etc.).

- the presence of constructions with a bare subject (with an indefinite nominal in the subject position); most are in postposition and belong to the class of the abstracts: Ce va să zică numărare? (5), Ce va să zică somare? (10), Ce lucru va să zică tragere? (17), Intoarcere nu va să zică altă färă decît a întoarce și a strînge multe rămășițe de rămășițe întru o singură rămășiță (51), pentru ca să se cunoască ce lucru este gheometrie (145).

- The apposition, poorly represented, has a structure that brings it closer to the attributive appositive constructions in the texts of the $16^{\text {th }}$ century, namely a proper name on the first position and an unarticulated common name on the second position: Vespasian impărat $(134,135)$.

\subsection{Lexicon}

4.3.1. The general neological lexicon is not well represented: arhistratijii ( pun oștile la orinduială, IV), dogmă (118), elementi (f.t.), elinei ( care acum să cheamă greci, 165), 2 haractiri (32: să faci o cruce în chipul unui her, puind deasupra una de aceste 2 haractiri, adecă:), legă 'league' (133), milă (133), răpublicile (IV), romei 'Greek from the Eastern Roman Empire' (165), stadie (133), tăbacă ( de Ispanie de cel bun, 88). The names of philosophers, writers or mathematicians are not numerous either: Abimede (sic! 160), Efclide (160), Orighen (III), Tertulian (III).

4.3.2. The specialized lexicon (algebra) is rich, with a varied component (lexical loans, lexical calques, popular terms):

- names of disciplines: aritmetică (II, III, 1 , aritmetică speculativă, 1 , aritmetich $i$, IV, dintr-alte aritmetici, 113), of specialists: aritmetecii (112), matimaticii (137) and of the tools used: abaco (24), tabla pitagorica 'multiplication table' (24).

- arithmetic operations, their terms and result: a cfadra 'to square / raise to the second power' (de a le face a lor some a le cfadra și a le trage rădăcina de numere, 141, a cfădra, 146: numere și a trage rădăcina cfadratului), cfadratu 'square of a number' ( lui 30, 153, trage cfadratu de la 30, 153), cfädrare (150), număr cub (156), numinătoriu 'denominator” (43, 43, 47, etc., numinătorii, 80), rădăcină cubă (156), soma (5, somele, 50, somi, 64, somile, 94, incredințarea somii, 15, soma de tot 'total', 30, 31, etc.), somare (6,15, somări, 69), somează (15, somîndu-se, 126, figurile somate, 16).

- arithmetic terms: cifra (4, tifra, 2, 29, 148, tifrele, 31), cubă, adj. (156), membro (10, un membro de la period, 8, membro de dilioane, 9, membro intreg, 10, care este membro dilioanelor, 10, doaî membri, 8), period (7, periodul, toate perioadele, 8, cîte perioade vor fi, 9), punt (8, pontu, 138, punte, 9, ponte, 141).

- numbers (some obtained by means of calque): zecina (2, zăcina, 11, zecinele, 12), milion (9, It. millione), dilion 'billion' (9, dilioane, 9, It. billion), trilioan 'one thousand billions; trillion' (9, trilioane, 9, It. trillion), patrilioane 'quadrillion' (9, It. quatrillion), cincilioane 'quintillion' (9, It. cinquillion).

- calques: agiunge 'to add' (< It. aggiungere: 40, 41, 103, etc.), atocmări 'proportion' (138), ieşire 'result' (82, 90, etc.), (numărul) ieșit 'product' (24), impărțire (6, 35), impărțitoriul (32), inchipuire 'example” $(18,21,36)$, incredințare 'verification” (22), inmulțire $(6,79$, inmulțirea în cruciş, 79), înmulțitoriu (24, 31, număru inmulțit, 31), lucrare 'mathematical operation' (36), nimică 'zero' (2, 16, rămasără patru nimicuri, 53), numărătoriu (42, numărătorii, 81, numărul numărătoriu, 47), numere neatocmate 'numbers without common divisors' (42), orînduială 'rule' (30; 158, mai are o dogmă, că să cheamă orînduiala înmulțitoare, 119 , orînduiele aritmeticești, 58), orînduiala de trei încă și de aur 'rule of three' (95, orînduiala de trei, 96, rînduiala de trei, 35), orinduiala de 5, 7, 9, 11 drepte și intoarse 'simple and inverse' (112), petrecătoriu, cuprinzătoriu 'quotient' (35: ce iese de la împărțire să zice petrecătoriu ori cuprinzătoriu, care să înțelege că, împărțindu-să un număr, în cîte părți să va împărțti, de atîtea ori se va cuprinde impărțitoriul; numărul petrecătoriu, 40), preț 'value' (46), prețuire 'estimation, evaluation' (59, orînduiala prețuirii, 59), să prețuiește (45, prețuindu-să, 45, să seprețuiască în bani, 120), rădăcina 'root (of a number)' (150, 151, etc.), rămăşiță 'remainder' (14), 'fraction' $(41,42)$, a schimba 'to sim- 
plify' (45, 47: vrînd să se schimbe într-o numire mai mică această rămășiță), soție 'parity' (96, numărul care are soție 'even', 96, fară de soție 'odd', 96), stîlp 'column of a table' (26), unime 'unity' (5).

- popular terms (simple or complex): indoiește 'to double' (149, 154), numărare (6), număr mare 'minuend' (23), număr mic 'subtrahend' (23, numărul ce să trage, 19), numărul ce să înmulțeste 'multiplicand' (30), numărul ca să se impărțască 'dividend' (35), imprumuta (22), pogoară (21, 103, țifra, $152)$, tragere 'subtraction' $(6,17$, etc.).

\subsubsection{Specialized lexicon (geometry):}

- terminological terms and phrases that refer to the discipline (related disciplines) and to the specialists: gheometrie (131, def.), gheometria practica (131, 132), (gheometria) speculativa (131); aritmetica gheometricească (146), aritmetica gheometrii [i] (131); astronomii (134), cozmometri 'topographer' (132), gheometrii $(134,137)$.

- two-dimensional geometric figures (figură gheometricească, 140): angol (140, angoli, 140, 159), angol drept (141, angolu drept, 143), angol ascuţit (141, angolu ascuțit, 143), angol tîmpit (141), (angolu) otuzo (142), cerc (160), cfadratu 'square' (144, 146, cfadrate, 119, cfádrate, 140, 141, cfadru, 161, cfädratu întocma (141, au rătund, 146), cfädratu lung 'rectangle' (141), cfadratu rombo 'rhombus' (159), linie (10, liniile, 139, linee, 165, linéia, 158, linéi, 141, linéile, 166), rombóide (141, rómboide, 160), rombu (141, rombo, 144, un rombo, 159, fața rómbolui, 160), scaleno 'triangle with all sides of different lengths' (142, scalenu, 157, fața figurii scalenuluiși a optusului au tîmpit, 157), scfadrile 'quadrilateral' (141), triangoli (140, triangolile, 162, triangole, 158), triangolu ecfilateru (158), (triangolu) isocile (141).

- fundamental notions: arc (139, arce, 140), chendru (139), diametru (139), oblicfä (140), (linie) perpendicolare (140, 158), paralele (140), rază (139), semidiametru (139); angular measurements: grad (133, grade, 140), minute (140), second (140, seconde, 140), terți (140).

- calques: fața 'surface' (157, 160, etc., fețele figurilor, 155), linie dreaptă (138: Linia dreaptă este ca o sfară întinsă între doao cuie), linie strîmbă au călcată 'open curved line' (138, 139: Linia strîmbă au călcată este ca cum ai lăsa cé întinsă în voia ei, de să strîmbează), linie boltită 'curved line' (138, 139: Linia boltită este ca o jumătate de cerc care să fie deasupra), linie scăfată 'curved line' (138, 139: Linia scăfată este cumu-i altă jumătate de cerc care este dedesupt, fața deasupra este ca o frunză netedă și dintraceste linii fac linia cercului, că să cheamă linia de prin prejur), impregiurare 'circumference' (160, 161, linia de prinprejur, 139), strună 'chord of a circle' (139: linia care să prinde în capetele arcului o numesc strună), (angol) tîmpit' 'obtuse' (141).

- popular terms: grosime (137), lat 'side' $(158,159$, lati, 160: iară în rómboide, că este de 2 lati mai lungiși 2 mai scurte), lărgime (117), lățime (137), lungime (137), măsurătorii de pămînt 'topographers' (158), nălțime (117).

\subsection{Glosses}

Glosses, explanatory structures, appear only in the text of the work, the new term (sometimes the old ones) being equated by means of: a) synonyms: oblicfă adecă plecată (140), fața figurii scalenului și a optusului au tîmpit (157), (angolu) otuzo ori angolu tîmpit (142), angolu drept ori îndreptariu (159), (număr) petrecătoriu ori cuprinzătoriu (35), unire ori strîngere (10), etc.; b) phrases: aritmetichi, adecă știința numărării (IV), capete au numere întregi (62), de cozmometri, adecă de măsurătorii lumii (132), grad de-a meridianului au a cercului de amiazăzi (133), linia cercului, că să cheamă linia de primprejur (139), Numărul este o adunătură de unime ori de lucruri adunate (5), etc.; c) broader explanations: paralele adecă întocma cu altele de măsură și îndreptare unele de altele (140), linia perpendicolare adecă cé de pre mijlocul ce pogoară în gios (157), scfadrile adecă cfädrate de multe feliuri, cumu-i cfădratu întocma, cfádratu lung, rombu, rombóide (141), tabla pitagorica, adecă cel abaco care să găsește în tot locul, măcar pînă la 10 cîte 10, că, neștiind aceasta, faci cu greu înmulțirea au și nu poți (24), triangolu ecfilateru, adecă în toate părțile intr-un chip (158), etc. 


\section{Aspects of phonetic and morphological adaptation}

The vast majority of new terms, including terminological phrases: cfädratu întocma (au rătund) (It. quadro perfetto), cfädratu lung 'rectangle' (It. quadro lungo), cfadratu rombo (It. quadro rombo), triangolu ecfilateru (It. triangolo equilatero), triangolu scaleno (It. triangolo scaleno), număr cub (It. numero cubo), rădăcină cubă (It. radice cuba), etc. are borrowed from Italian.

Their aspect is due to the pressure exerted by the Italian text on the Moldavian scholar, being illustrative for the difficulties related to the various aspects of phonetic and morphological adaptation: abaco, angol, elementi, isocile, lineia, membro, otuzo, perpendicolare, punt, rombo, scaleno, seconde, soma, triangol. Certain masculine and neuter terms are observed to have a vowel ending, which would later on be eliminated, under the influence of the French language, the nouns in question receiving, in most cases, a consonant ending or the $-u$ vowel. The situation is sporadically illustrated in the text: rombo - rombu, scaleno - scalenu. Some loans have affixes specific to the inflection of the target language, which demonstrates the adaptation attempt by attaching the Romanian inflection marks: membri, optusului, rombolui, scalenului. Some neological terms develop relatively rich families: cfadru, cfadra / cfädra, cfädrare, cfädrat; somă, somare, a soma, somat. Relevant to the difficulties of adaptation are also the fluctuations of accentuation or in the adoption of one form or another: rombóide - rómboide; linia - linii, linee, linéia - linéi, optus - otuzo, punt-punte, pont-ponte.

Under the influence of neo-Greek pronunciation, the $q u$ digraph appears in the (old) form $c f: c f a d r a t$ I cfädrat, cfadru, cfadrare, ecfilater, oblicfă, scfadrile. The succession eu > ef, also due to the Greek pronunciation: Efclide. The consonantal group $c t$ appears reduced, compared to the Latin-French aspect of the variants imposed in the literary language: pont, punt, but: gheometria practica (It. geometria pratica).

There is also the older model of adaptation with the affricates $t, g$, , and $\kappa$ : chendru, gheometrie, Orighen, tifră. The affricate $\breve{g}$ appears rendered by the voiced fricative $j$ : arbistratijii (with the closure of medial $e$ into $i$ ). As for the consonant group $c h$, it appears rendered by $b$ : haractiri (with the closure of medial $e$ into $i$ ).

As far as the gender classification is concerned, one can notice the distribution in the neuter class of some nouns that will later on be established in the feminine category: period, second and vice versa: tăbacă and in the masculine of certain nouns that will be set to the neuter gender: triangoli. Fluctuations are also observed in the formation of the plural: some - somi, triangoli-triangole. Nouns of professions have forms influenced by the Italian: aritmetecii, matimaticii, gheometrii. Adjectives have, in most cases, the -icesc suffix: aritmeticești, gheometricești, but also - ic, in alternating forms: elementi aritmetice (f.t.) orînduiele aritmeticești (58), pasu gheometricu (132) - pasu gheometricesc (163).

There are many terms that appear for the first time in this text: oblicfä, ecfilateru, membri (parts of a mathematical phrase), optus, paralele, rombu, romboide, scalenu, second, -e, speculativă, sometimes ahead of the attestations: abaco, gheometru, linie, romeu, semidiametru, terți (unit of angular measure, one-sixtieth of a second), trilioan / trilioane, whilst a term, elinei, explained care acum să cheamă greci (appears in the same context as the lexeme romei), is not registered in dictionaries.

\section{Conclusions}

The translation of Bishop Amfilohie provides us with valuable information on the Romanian literary language in Moldavia at the end of the $18^{\text {th }}$ century. The linguistic analysis of the text reveals specific features of the Moldavian language, but also of the literary language at the end of the $18^{\text {th }}$ century: the closing of the atone medial $e$ into $i$, the reduction of the diphthong $e a$ to $e$, the change from $i a$ to $i e$, the hardening of the $s, j, t, z$ consonants, these alternating with the weak ones (the ratio is variable from one case to another), a balanced ratio between the phonetisms with $j$ and $\breve{g}$, soft $r$ in the derivatives with -tor, alternation between the forms with restored dental and the iotacized ones, invariability of the possessive mark, the old form of the imperfect indicative with the generalized au auxiliary. The situation in the 
nominal group is very interesting (high frequency of analytical structures for marking the genitive alternating with synthetic ones, frequency of nominal groups with nominal center in the genitive in which the determiner is indefinite, appearance of unarticulated nominals in subject position, old forms of certain determiners, the use of $c \breve{a}$ with a relative value, etc.), as well as in the verbal group (where we can notice the preservation of some linguistic facts specific to the older period, such as the various ways of expressing the future, the strong paradigm of the verb $a d a$, verbs and verbal constructions calqued after Italian etc.).

The text also provides us with valuable information on the difficult process of forming mathematical terminology. The specialized lexicon illustrated by the two subdomains (algebra and geometry) is relatively rich and varied, consisting of lexical borrowings (most of them keeping the etymological form), calques and popular terms. Amfilohie's work, which, before being printed, circulated in numerous manuscript copies, thus having a wide circulation, nevertheless failed to impose specialized terminology, consisting of many unadapted lexical borrowings and cumbersome calques. However, the Italian phonetic variants are very important for studying the influence of this culture language on the Romanian language, having an important role in creating a linguistic framework conducive to the introduction of a large number of Latin-Romance neologisms and, consequently, in modernizing the Romanian lexicon.

\section{Bibliography}

Dima, E. \& Dima, G. (2016). Traducătorii români și traducerile laice din secolul al XVIII-lea, Editura Universității "Alexandru Ioan Cuza”, Iași.

Frâncu, C. (2009). Gramatica limbii române vechi (1521-1780), Casa editorială Demiurg, Iași.

Hoinărescu, L. (2016). Genitivul cu prepoziţia de în limba română. Operspectivă diacronică și funcţională, in "Studii și cercetări lingvistice”, LXVII (2), p. 227-256.

Pană Dindelegan, G. (ed.) (2019). Sintaxa limbii române vechi, Editura Univers enciclopedic Gold, București.

Popa, I. (1938). Le modèle italien d'un ancien traité roumain d'arithmétique, in "Archeion”, XIX (1-2), p. 69-73.

Stan, C. (2013). O sintaxă diacronică a limbii române vechi, Editura Universității din București, București.

Șuiu, R. (1979). Amfilobie Hotiniul, in Dicționarul literaturii române de la origini pînă la 1900, Editura Academiei, București. Ursu, N.A. (1962). Formarea terminologiei științifice românești, Editura Științifică, București, 1962. 